\title{
Fiscal redistribution and public support for European integration ${ }^{1}$
}

\author{
Forthcoming in European Union Politics
}

\author{
Adam William Chalmers ${ }^{2}$ \\ $\&$ \\ Lisa Maria Dellmuth ${ }^{3}$
}

\begin{abstract}
This article contributes to existing debates on public opinion towards European integration by examining when and why fiscal transfers and public support are systematically related. Drawing on economic and identity-related theories, we develop and test hypotheses about the links between EU fiscal transfers among countries and subnational jurisdictions, and citizens' support for European integration. Using a three-level analysis of residents in 143 regions in 16 EU member states, we find a positive effect of EU transfers among both countries and subnational jurisdictions on support for European integration among those with a European communal identity. We also find that this effect increases the more politically aware individuals are. The article sketches the broader implications of our findings for public opinion research on regional integration beyond the European Union.
\end{abstract}

\footnotetext{
${ }^{1}$ Both authors contributed equally to this article.

${ }^{2}$ Assistant Professor at Leiden University, a.w.chalmers@fsw.leidenuniv.nl.

${ }^{3}$ Postdoctoral researcher at Stockholm University, lisa.dellmuth@statsvet.su.se.
} 
When and why does the redistribution of fiscal transfers by regional organizations affect citizen support for regional integration? This is a central question for scholars of public opinion towards what amounts to a growing number of regional organizations world-wide, ranging from mere free trade areas, like the North American Free Trade Organization, to more fully integrated economic and political regions like the Association of Southeast Nations, the African Union, and the European Union (EU). Supportive public opinion is central for the effectiveness of any political institution, influencing its capacity to compel compliance with the institutions' aims and to command social control. This is especially important for multilateral organizations, which typically lack means of coercion as an instrument of social control and thus depend on the voluntary compliance of national governments (Hurd, 1999). Public opinion, by way of shaping mass political behavior, may affect national governments' compliance with international policy if citizens form powerful domestic constituencies (Gabel, 1998a; Mansfield and Milner, 2012; Tomz, 2007).

This article examines the conditions under which fiscal transfers through the EU budget affect public support for European integration. The question of public support towards European integration has been the subject of a great deal of scholarly attention (Eichenberg and Dalton, 1993; Gabel, 1998b; Harteveld et al., 2013; Hooghe and Marks, 2004, 2005; Karp et al., 2003; Maier et al., 2012). Importantly, much of this research turns on a central theoretical debate regarding the determinants of support. In particular, a fundamental divide separates so-called 'economic theories' of support, where individual attitudes are determined by a rational cost-benefit analysis of the distributional outcomes of integrative processes, and ‘identity theories' of support, where individual attitudes are largely a function of social identity. In this article, we argue that important questions left open in these two lines of theory concern the mechanisms linking fiscal redistribution through the EU and public support for European integration. Is the association between fiscal transfers and support owing to political 
predispositions such as identity (Anderson and Reichert, 1995; Harteveld et al., 2013; Hooghe and Marks, 2005; Karp et al., 2003)? How do existing individual identities filter information about fiscal transfers and, in turn, affect the link between transfers and support for European integration? Furthermore, does the effect of fiscal transfers on support differ among politically aware and unaware individuals? Do national political elites shape the way in which individuals perceive fiscal transfers through the EU's budget and link these perceptions to their support for European integration? These are important questions given that citizens possess a variety of political predispositions and experiences that may greatly affect their willingness to accept - or alternatively, their resolve to resist - persuasive influences coming from the EU or national elites (see Zaller, 1992).

Advancing on insights in the existing literature, we posit that support for EU integration depends on fiscal redistribution through the EU budget insofar as individuals are already predisposed to evaluate fiscal transfers in a positive or negative light. In this respect, fiscal transfers to a citizen's country or subnational region of residence ${ }^{\mathrm{i}}$ may affect, by way of being filtered through the individual's predispositions, that citizen's support for European integration. To anticipate the main findings of this article, we demonstrate, using a statistical analysis of public opinion in 143 subnational jurisdictions in 16 EU member states, robust evidence that: a) the positive effect of EU fiscal transfers to countries and regions on support for European integration is stronger among people with a European communal identity; b) the positive effect on support of transfers to countries and regions increases the more politically aware individuals are; and c) those exposed to national political parties that are positively predisposed towards European fiscal redistribution are not more likely to link EU transfers to their support for European integration.

These findings have three main implications for our understanding of the impact of fiscal redistribution in the EU on public support for European integration as well as a broader 
literature on other instances of regional and trade integration. First, that the effect of fiscal transfers on support is contingent on individual identity begs questions about the potential of EU fiscal redistribution to increase EU support. For all the talk about the importance of redistribution through the EU budget to make public opinion more favorable towards European integration, an effect of redistribution on support may not be in the hands of European policy-makers but ultimately depend on citizens' social identity. This assessment ties in with previous EU public opinion literature showing that identity is a key predictor of public support for European integration (e.g., Hooghe and Marks, 2004, 2005; Kriesi and Lachat, 2004). Second, our results suggest that fiscal transfers to subnational jurisdictions increase support only among the politically aware, whereas the effect of country transfers is not mediated by political awareness. This finding stands in contrast to previous evidence for a direct effect of fiscal redistribution among countries on support for European integration (Anderson and Reichert, 1995; Gabel and Palmer, 1995; Harteveld et al., 2013; Hooghe and Marks, 2005; Karp et al., 2003). Given that fiscal redistribution to regions amounts to more than one third of the EU budget, this implies that large parts of the allocation of the EU budget may proceed beneath the radar of the public. Third, we contribute to scholarship on public opinion towards integration processes beyond the EU. Importantly, we add new knowledge to the debate about the relative explanatory power of economic and identityrelated factors in explaining public support for European integration and other instances of sectoral or regional integration. As we show, the effect of EU transfers on support for European integration depends on identity but not on economic considerations. Moreover, the effect of European communal identity on support is stronger than the effect of economic considerations. In this respect, we complement similar findings in previous works on public opinion on trade integration and regional integration in Northeast Asia (Jhee, 2009). 


\section{Fiscal redistribution and citizen support for regional integration}

The existing literature on public opinion towards regional and trade integration turns on a pivotal debate between economic theories and identity-based theories. A central purpose of this analysis is to bridge the gap between these theories and provide more explicit theorizing about how fiscal redistribution in the EU affects public support for European integration. Before presenting the theoretical framework used in this analysis we first provide a brief overview of the two theories.

In removing barriers to capital and labor mobility as well as facilitating economic exchange, processes of sectoral and regional integration have led to (sometimes radically) uneven economic consequences, with some individuals experiencing more economic benefits than others. As such, economic theories explain public support in terms of individual levels of satisfaction with regard to these different outcomes, especially as it is felt in the individual's pocketbook (Scheve and Slaughter, 2001). Economic theories, in other words, explain public support as a function of an individual's rational cost-benefit analysis of the redistributional consequences of broader integration processes. Economic theories have gained considerable traction in terms of regional integration processes. Various studies have found higher levels of support among individuals whose country of residence profited from resource redistribution specifically through the European budget (Eichenberg and Dalton, 1993; Karp et al., 2003) as well as those who benefit individually more from European integration than others (e.g., Gabel, 1998a, 1998b; Gabel and Palmer, 1995).

Identity-based theories of support take issue with the overly deterministic assumptions linking individual cost-benefit analyses to variation in levels of public support. For these scholars, support is largely determined by an individual's set of 'relatively stable symbolic predispositions’ (Fordham and Kleinberg, 2012: 312). Support has been explained in terms of 'nationalistic attitudes' (e.g., Mayda and Rodrik, 2005), individual attachment to national 
sovereignty and conceptions of national identity, existing national identities and cultures (e.g., De Vreese and Boomgaarden, 2005; Kriesi and Lachat, 2004), and general value orientations (e.g., Edwards, 2006). Similarly, research focusing specifically on the EU shows that individuals with 'multiple identities' (those who identify as both French and Spanish or French and European, for instance), 'inclusive identities’ (Hooghe and Marks, 2005: 424), or so-called communal identities shaped by a common liberal democratic constitution like the European treaties (Bruter, 2004) feel less threatened by EU integration and therefore tend to be more supportive of European integration. Identity-related theories also posit that support is related to the extent to which individuals are politically aware of the distributional consequences of integration (Inglehart, 1970). Greater political awareness predisposes individuals to evaluate their life circumstances through a particular lens. Furthermore, individual predispositions have been extensively researched in terms of their effect on the association between political party communication and public support. Party cues related to regional integration have been found to be more effective when leveled at individuals who are predisposed to being receptive to such messages (Gabel and Scheve, 2007).

Our argument brings together insights from both economic and identity-based theories of support. Economic theories suggest that the distributional benefits of integration change an individual's socio-economic circumstances but fail to show how these changed circumstances get translated into more a positive perception of integration. Identity-based theories are well suited to explaining variation in individual attitudes but people's feelings of allegiance to different collective groups have not yet been theorized as mediating the association between the distributional outcomes of regional integration and public opinion. Advancing on the existing literature, our central argument is that support for regional integration depends on the degree to which citizens are predisposed to evaluating the distributional outcomes of integration. In short, support is a function of how distributional outcomes are filtered through 
the lens of existing individual predispositions, such as identity and political awareness. Starting from this argument, the next section develops testable hypotheses in the context of fiscal redistribution in the EU.

\section{Fiscal redistribution and citizen support for European integration}

Our central insight in this article is that fiscal transfers through the EU budget do not simply create economic winners and losers. We acknowledge that transfers may 'add wealth to the economies of the net recipients and remove wealth from the economies of the net contributors', thereby giving recipients 'an additional incentive to support integration, while net contributors may have an additional incentive to oppose it' (Carrubba, 2001: 149). Furthermore, we argue that transfers may positively affect support for European integration insofar as they signal a form of economic solidarity across people in different EU member states. In particular, fiscal transfers to subnational authorities through the so-called Structural Funds, which amount to more than a third of the EU budget, not only aim at mitigating Europe's economic disparities, but also at increasing social cohesion amongst EU citizens (see Dellmuth, 2011). Hence, at the individual level citizens in a particular region receiving more Structural Funds might perceive these funds as a sign of solidarity from other EU member countries. However, the ability of individual citizens to interpret financial gains in this manner depends on the extent to which they are already predisposed to doing so. Bringing in insights from identity-based theories of support, we argue that variation in how individuals interpret the receipt of EU transfers may be a function of three mechanisms: (1) a positive pre-disposition to European integration; (2) the capacity to receive and interpret signals of economic solidarity; and (3) political parties' stance on supranational redistribution and the EU integration project as a whole. These three mechanisms lead to a series of complementary 
hypotheses about the links between public support for European integration as well as national and subnational transfers, respectively.

First, a positive predisposition refers to an individual citizen's existing social identity. Existing research suggests that individuals with 'communal' or European identities tend to be more supportive of EU integration than those with so-called 'exclusive identities' shaped by a common history and shared territory (Hooghe and Marks, 2005). While there is an ongoing debate about whether entrenched national identities are directly linked to Euro-skepticism (Christin and Trechsel, 2002) or whether this effect depends on other factors (Carey, 2002; Hooghe and Marks, 2005), communal identity is commonly found to be related to more proEU sentiments and therefore a predisposition to evaluate the EU in a positive light (Carey, 2002; Hooghe and Marks, 2005; see also Bruter, 2003).

Identity therefore mediates how citizens understand EU transfers. There are two considerations to make regarding identity. A first consideration, and following insights from the existing literature, is the direction of identity. Individuals are variously predisposed to interpreting fiscal transfers depending on whether they have exclusive national or communal identities. Those with an exclusive identity will interpret fiscal transfers negatively, either disregarding transfers as insignificant or understanding them as further evidence of the encroachment of the EU into national politics and related threats to national identities and cultures. By contrast, those with communal identities will interpret transfers positively, understanding transfers as evidence of the benefits of integration, highlighting the extent to which transfers reflect spreading economic solidarity amongst EU citizens across the various member states. Importantly, in both cases transfers do not merely confirm citizens' existing perceptions about the EU, but strengthen them. These insights lead to our first hypothesis. 
H1a: Larger amounts of EU transfers for a country or region will increase public support in that region or country among those individuals having a European communal identity.

Second, we consider the strength of identity to further qualify the prediction made in H1a. Individuals differ not only with regard to whether they identify with a European community or not but also with regard to how strong their sense of identification is (Carey, 2002; Marks, 1999: 72). A relatively strong national exclusive identity refers to a strong social bond with the community of people living in the same country, whereas a relatively weak national identity would be found among those considering themselves as mere inhabitants of their country without feeling a particularly strong social bond with other citizens. Similarly, citizens with a relatively strong European identity have a more pronounced sense of identification with other European citizens, while a relatively weak European identity is a hallmark of those who feel less strongly attached to the EU or other EU citizens. .

Among individuals that have a European communal identity, those who strongly identify with a European community may not be inclined to change their opinion of European integration based on the receipt of financial transfers. In these cases, transfers may do little more than confirm these individuals in their existing positive perceptions about the EU. Indeed, even those with strong communal identities may take financial transfers for granted and do not need to experience further signs of economic solidarity to form their opinions about integration. Where national and subnational transfers matter most, however, may be in cases where citizens exhibit a weaker sense of identification with the European community. These citizens may be more predisposed to having their opinions about the EU swayed by EU transfers. As such, financial transfers may have the potential to change opinions only for those with weak identities. These insights lead to a second hypothesis that further specifies H1a: 
H1b: Larger amounts of EU transfers for a country or region will increase public support in that region or country among those individuals having a relatively weak European communal identity.

Second, an individual's capacity to receive and understand signals of economic solidarity derived from the receipt of fiscal transfers requires a certain degree of political awareness. Well informed individuals with high levels of education and access to broad communication networks are better positioned to receive and understand these signals as well as to evaluate them in a positive light (Inglehart, 1970; Inglehart and Rabier, 1978: Caldeira and Gibson, 1995). The same individuals are less threatened by processes of global integration (Kaltenthaler et al., 2004), have a more cosmopolitan perspective (Inglehart, 1970), and are more supportive of international organization (Caldeira and Gibson, 1995). By contrast, less politically aware individuals have greater difficulty in understanding the world 'beyond their locality, because they do not know about it or understand it' (Kaltenthaler et al., 2004: 834). Political awareness is particularly important for EU fiscal transfers. Both net transfers to countries and Structural Funds allocations to regions are, at root, redistributive policies channeling funds from the 'haves' to the 'have-nots' (Dellmuth, 2011). To interpret these policies in terms of economic solidarity requires a certain degree of awareness about European redistribution and the extent to which a particular region's funding originates from net EU contributors. Moreover, Hooghe and Marks (2005: 422) point out that 'the economic approach to public opinion is likely to be most valid when economic consequences are perceived with some accuracy'. In this respect, previous research has provided evidence that economic changes brought about by EU integration are particularly salient for politically aware individuals who are well-positioned to take advantage of further integration (e.g., Caldeira and Gibson, 1995). This leads to the following hypothesis. 
H2: Larger amounts of EU transfers for a country or region will increase public support in that region or country among individuals who are more politically aware.

Third, and related, citizens may interpret the economic benefits of redistribution through the EU budget for their region or country in a more positive light if national political parties are strong supporters of supranational redistribution (Zaller, 1992; Hooghe and Marks, 2005). Like political awareness, political parties may cue individuals in a way that allows them to both understand the potential benefits of supranational redistribution as well as to make a link between fiscal transfers and the role of the EU in their own region or country with regard to improving their life circumstances (cf. Carrubba, 2001). This leads to our third hypothesis.

H3: Larger amounts of EU transfers for a country or region will increase public support in that region or country the more national political parties favor European fiscal redistribution.

\section{Research design}

To examine the relative explanatory power of the hypotheses, we have compiled a data set from a variety of sources. Since the hypotheses predict effects on public support for European integration of individual- and contextual-level factors, we use data at the individual, subnational, and country level. To measure these factors, we draw on the Eurobarometer (EB) 73.4 from May 2010. This is the only survey data set that allows for the operationalization of all hypotheses and for which expert survey data for the measurement of party positions measured in the same year are available. Since the hypotheses predict effects of EU transfers to subnational jurisdictions, our analysis includes only member states where subnational jurisdictions receive such transfers. ${ }^{\text {ii }}$ The remainder of this section discusses the operationalization of the hypotheses and alternative explanations in detail. ${ }^{\mathrm{iii}}$ 


\section{Operationalization of the dependent variable}

We measure Support for European integration by using responses to the following EB question:

Generally speaking, do you think that (our country’s) membership of the European Union is: 0 (a bad thing), 1 (neither good nor bad), or 2 (a good thing)?

Given the centrality of European support scales in the EU public opinion literature, previous authors have debated the validity of this measure, providing evidence that respondents who support EU membership generally also support more specific integrative measures (e.g., Gabel, 1998a, 1998b). The variable thus captures citizens' short-term satisfaction with specific EU outputs as well as long-term attachment to the EU that is not contingent upon the satisfaction with specific outputs.

\section{Operationalization of hypotheses}

To begin with, we need measures for national and subnational transfer payments through the EU budget. EU transfers are allocated under the auspices of the 'financial perspective', a budgetary plan that fixes transfers for a seven-year period, ${ }^{\mathrm{iv}}$ leaving very little leeway during annual budgetary negotiations (Schneider, 2013). Subnational transfers are channeled through the EU budget as well and are therefore captured by our measure for national transfers. However, these two types of transfer payments are the result of different political negotiation processes and therefore subject to different allocation criteria. Whereas national transfers are decided during budgetary negotiations in the Council of Ministers, subnational transfers are decided through negotiations between subnational and national governments as well as the European Commission (Chalmers, 2013). First, we measure National transfers as net fiscal transfers as a percentage of a country's gross national income (GNI) by using the average for the financial perspective 2007-2013 (European Union, 2014: appendix 3). Second, as 
subnational transfers cannot be measured in terms of net or gross benefits since regions do not contribute to the EU budget, we code Subnational transfers as the total sum of Structural Funds investment in a region in 1000 Euro per capita during the period 2007-2013 (European Commission, 2014). Table A4 in the online appendix provides an overview of the regions and the number of individuals in each jurisdiction. ${ }^{\mathrm{v}}$ We use aggregate measures for the whole budgetary period and not annual measures for 2010 or the period between 2007 and 2010 since we expect the negotiation outcome of the financial perspective to be more contentious and, in turn, publicly visible than the bargaining outcome of annual budgetary decisionmaking. However, we illustrate the robustness of the results through a replication of the regression models with alternative transfer measures, as discussed below. ${ }^{\mathrm{vi}}$

H1a and H1b require measures for communal identity. Previous literature has used a question about territorial attachment to measure identity (Hooghe and Marks, 2005), which taps people's cultural identity regardless of the political system in which people live. Such a specific measure, however, is not available in the EB data. As such, we opted for responses to a question about the extent to which people feel that they are EU citizens (EB 73.4). To operationalize H1a, we create a variable Direction of identity ranging from 0 (definitely not), 1 (not really), 2 (to some extent), to 3 (definitely). This variable captures communal identity as an identity that is not a function of a common history or territory but shaped or generated by a common liberal democratic constitution, such as the European treaties (see Bruter, 2004). Testing H1b uses the same EB data but recoded in a way that captures strong and weak identities. Specifically, those with strong feelings of EU citizenship (0 and 3) are recoded as 0 while those with weak feelings of EU citizenship (1 and 2) are recoded as 1 . The resulting variable is Strength of identity.

To operationalize H2, we create two variables tapping political awareness, defined as the ability of citizens to receive and understand new information about politics (Zaller, 1992: 
21; see also Gabel and Scheve, 2007). First, we use a measure of education, since formal education equips individuals with the necessary cognitive skills to comprehend and process new political information (Delli Carpini and Keeter, 1996: 192-193; Luskin, 1987). We include Education as a 9-point indicator measuring at what age a respondent has finished formal education (see Zaller, 1992). It is coded 1 if the respondent was14 years or younger and 9 if she or he was 22 years or older (cf. Caldeira and Gibson, 1995). Second, we create a variable Discussion using the responses to an EB question about the frequency of discussing political matters with friends, coded 0 (never), 1 (occasionally), and 2 (frequently) (EB 73.4). Awareness is a multifaceted concept implying political interest, attentiveness toward politics, as well as the cognitive ability to retain and organize political information. This latter variable measures the frequency of interactions in environments that may facilitate the development and maintenance of political awareness (see Delli Carpini and Keeter, 1996).

For the purpose of operationalizing H3, we use a measure of political parties' stances on European redistribution for both the leading and the second leading parties that compete in national elections. ${ }^{\text {vii }}$ The variable Party positions on European redistribution is based on responses to a question about the overall orientation of the party leadership towards European cohesion policy from the 2010 CHES dataset (Bakker et al., 2012; Hooghe et al., 2010). ${ }^{\text {vii }}$ This question yields a 7-point measure ranging from 1 (strongly opposed) to 7 (strongly in favor). ${ }^{\text {ix }}$ In using this measure, we assume that all respondents receive cues from the largest national parties. National governments are the most important actors that negotiate the amount of structural funding with the European Commission and can therefore be expected to be driving public discourse about the EU Structural Funds and national transfer levels. 


\section{Operationalization of alternative explanations}

To control for potential alternative explanations of EU support, we create a variable Party positions on European integration by using CHES data that is coded on the same scale as the variable Party positions on European redistribution.

Furthermore, we control for variables that tap material self-interest and that tap respondents' economic prospects, skill level, and integration in societal organizations. Personal economic prospects is an additive index measuring expectations for the next twelve months concerning 1) a respondent’s life in general; 2) financial situation; and 3) job situation (EB 73.4). The indicators are each coded 0 (worse), 1 (same), and 2 (better), and the overall index ranges from 0 to 6 (Cronbach's alpha $=0.77$ ). To distinguish evidence of self-interest from sociotropic preferences, we include a measure of a respondent's evaluation of a Country's economic prospects, coded 0 (worse), 1 (same), and 2 (better) (see Carey, 2002; Hooghe and Marks, 2004). Furthermore, we capture respondents' skill level using a dichotomous variable coded 1 if a respondent is a Manual worker and 0 if otherwise. The variable is coded so as to distinguish between unskilled workers on the one hand and skilled manual workers and the remaining occupational categories on the other hand (cf. Hooghe and Marks, 2005). Furthermore, we measure GDP in purchasing power standards per inhabitant as a percentage of the EU average from Eurostat for the respondents' country of residence. This measure of GDP captures relative rather than absolute GDP and is the theoretically important variable in this context: economic theories predict an effect of the distribution of economic resources in the EU on an individual's support for European integration depending on where in the distribution of economic performance a respondent's country of residence falls. We test for an effect of material interests using a multiplicative term of Manual worker and GDP (cf. Hooghe and Marks, 2005). Last, we include a variable Union membership. While it is difficult to derive an expectation about the direction of a potential effect on support for European 
integration, union membership is likely to have an effect since frequent contact with people who have the same economic interests should affect people's collective identity and hence bias their view on European integration (cf. Fordham and Kleinberg, 2012).

Moreover, we test whether support is, at least in part, a function of a more general 'trust syndrome' (Harteveld et al., 2013: 561), whereby the legitimacy of the EU can be predicted to a significant degree by the legitimacy of domestic political institutions (see Anderson, 1998; Muñoz et al., 2011; Rohrschneider, 2002). Following this literature, we include a dichotomous measure Trust in government coded 1 if a respondent tends to trust government in her country of residence, and 0 if that person tends not to trust government (EB 73.4).

Lastly, we include two socio-demographic variables. Age enters the regression analysis as a continuous variable. Gender is a dichotomous measure coded 1 for females and 0 for males.

\section{Empirical analysis}

To test the relative explanatory power of the hypotheses, we estimate a series of three-level models with separate error components at the individual, regional and country level. In doing so, we adjust for the correlation of the error components between the three levels (see Goldstein, 1987). As the dependent variable Support takes on three ordered values, we estimate the models using ordered logistic regression. ${ }^{\mathrm{x}}$ The results from models $1-10$, testing our hypotheses, are presented in Table $1 .^{\mathrm{xi}}$ Table 2 presents different model specifications without the interaction terms that operationalize the hypotheses, providing additional tests for potential direct effects of EU transfer payments and of material interests through the interactive term between Manual worker and GDP. 
Table 1. Three-level models of Support - indirect effects

\section{Hypotheses}

Direction of identity * Nat. transfers

Direction of identity * Subnational t.

Strength of identity * Nat. transfers

Strength of identity * Subnational t

Education * National transfers

Education * Subnational transfers

Discussion * National transfers

Discussion * Subnational transfers

Party pos. on Eur. red. * National t.

Party pos. on Eur. red. * Subnat. t.

National transfers

Subnational transfers

Direction of identity

Strength of identity

Education

Discussion

Party positions on European red.

Alternative explanations $-0.10^{\star \star \star}$

(0.03)

$-0.00^{\star * *}$

(0.00)

0.03

(0.03)

$-0.00$

(0.00)

$-0.02^{\star *}$

(0.01)

-0.00 ***

$-0.08$

(0.05)

$-0.00$

(0.00)

$0.38^{\star \star *}$

(0.07)

0.00

(0.00)

$\begin{array}{cccc}0.13 & -0.03 & 0.15^{\star *} & 0.19^{\star} \\ (0.07) & (0.04) & (0.05) & (0.08) \\ -0.00 & 0.00^{\star} & -0.00^{\star *} & -0.00 \\ (0.00) & (0.00) & (0.00) & (0.00) \\ 0.94^{\star \star \star} & 1.03^{\star \star \star} & 0.88^{\star \star \star} & 0.87^{\star \star \star} \\ (0.05) & (0.07) & (0.04) & (0.04) \\ 0.04 & 0.04 & 0.01 & 0.03 \\ (0.06) & (0.06) & (0.07) & (0.08) \\ 0.10^{\star \star \star} & 0.10^{\star \star \star} & 0.10^{\star \star \star} & 0.10^{\star \star \star} \\ (0.01) & (0.01) & (0.01) & (0.01) \\ 0.01 & 0.01 & 0.01 & 0.01 \\ (0.05) & (0.05) & (0.05) & (0.05) \\ -0.08 & -0.07 & -0.10 & -0.10 \\ (0.06) & (0.06) & (0.05) & (0.05) \\ & & & \end{array}$

(2)

0.01
$(0.05)$
-0.00
$(0.00)$
$0.88^{\star \star \star}$
$(0.04)$
0.02
$(0.06)$
$0.12^{\star \star *}$
$(0.01)$
0.01
$(0.05)$
-0.07
$(0.06)$

0.25 *

(0.08)

$-0.00^{*}$

$(0.00)$

$0.10^{* * *}$

(0.01)

0.06

(0.05)

$0.88^{\star \star \star}$

(0.04)

0.02

(0.06)

$-0.09$

(0.05)
$0.17^{\text {***}}$
$(0.06)$

$0.04)$

$-0.00$

(0.00)

$0.10^{\star \star *}$

(0.01)

(0.06)

$(0.06)$

$.88^{\star * *}$

(0.04)

$-0.10$

(0.05)

$-2.35^{\star \star * *}$

(0.47)

$-0.00$

(0.00)

$0.88^{\star \star \star *}$

(0.04)

0.02

(0.06)

$0.10^{* * *}$

(0.01)

0.00

(0.05)

$0.28^{\star \star \star}$

(0.07) 


\begin{tabular}{|c|c|c|c|c|c|c|c|c|c|c|}
\hline Party pos. on European integration & $\begin{array}{c}0.05 \\
(0.03)\end{array}$ & $\begin{array}{c}0.05 \\
(0.03)\end{array}$ & $\begin{array}{l}0.07^{\star} \\
(0.03)\end{array}$ & $\begin{array}{l}0.10^{\star} \\
(0.04)\end{array}$ & $\begin{array}{l}0.07^{\star} \\
(0.03)\end{array}$ & $\begin{array}{l}0.10^{*} \\
(0.04)\end{array}$ & $\begin{array}{l}0.07^{\star} \\
(0.03)\end{array}$ & $\begin{array}{l}0.07^{\star} \\
(0.03)\end{array}$ & $\begin{array}{l}-0.11^{* *} \\
(0.04)\end{array}$ & $\begin{array}{l}0.08^{\star \star} \\
(0.03)\end{array}$ \\
\hline Personal economic prospects & $\begin{array}{c}0.09 * \star \star \\
(0.02)\end{array}$ & $\begin{array}{c}0.09^{\star \star \star} \\
(0.02)\end{array}$ & $\begin{array}{c}0.09 * * * \\
(0.02)\end{array}$ & $\begin{array}{c}0.09 * * \star \\
(0.02)\end{array}$ & $\begin{array}{c}0.09^{\star \star \star} \\
(0.02)\end{array}$ & $\begin{array}{c}0.09 * * * \\
(0.02)\end{array}$ & $\begin{array}{c}0.09 * * \star \\
(0.02)\end{array}$ & $\begin{array}{c}0.09^{\star \star \star} \\
(0.02)\end{array}$ & $\begin{array}{c}0.09 * * * \\
(0.02)\end{array}$ & $\begin{array}{c}0.09^{\star \star \star} \\
(0.02)\end{array}$ \\
\hline Country's economic prospects & $\begin{array}{c}0.20^{\star \star \star *} \\
(0.05)\end{array}$ & $\begin{array}{l}0.21^{\star \star \star} \\
(0.05)\end{array}$ & $\begin{array}{c}0.20^{\star \star *} \\
(0.05)\end{array}$ & $\begin{array}{c}0.20^{* * *} \\
(0.05)\end{array}$ & $\begin{array}{l}0.21^{\star \star \star} \\
(0.05)\end{array}$ & $\begin{array}{c}0.20^{* * *} \\
(0.05)\end{array}$ & $\begin{array}{c}0.20^{\star * *} \\
(0.05)\end{array}$ & $\begin{array}{c}0.21^{\star \star *} \\
(0.05)\end{array}$ & $\begin{array}{c}0.20^{* \star *} \\
(0.05)\end{array}$ & $\begin{array}{l}0.20^{\star \star \star *} \\
(0.05)\end{array}$ \\
\hline Union membership & $\begin{array}{c}0.04 \\
(0.15)\end{array}$ & $\begin{array}{c}0.04 \\
(0.15)\end{array}$ & $\begin{array}{c}0.06 \\
(0.15)\end{array}$ & $\begin{array}{c}0.05 \\
(0.15)\end{array}$ & $\begin{array}{c}0.05 \\
(0.15)\end{array}$ & $\begin{array}{c}0.04 \\
(0.15)\end{array}$ & $\begin{array}{c}0.05 \\
(0.15)\end{array}$ & $\begin{array}{c}0.05 \\
(0.15)\end{array}$ & $\begin{array}{c}0.06 \\
(0.15)\end{array}$ & $\begin{array}{c}0.06 \\
(0.15)\end{array}$ \\
\hline Trust in government & $\begin{array}{c}0.90^{\star \star \star *} \\
(0.08)\end{array}$ & $\begin{array}{l}0.90 * \star \star \\
(0.08)\end{array}$ & $\begin{array}{c}0.91^{* * *} \\
(0.08)\end{array}$ & $\begin{array}{c}0.92 * * * \\
(0.08)\end{array}$ & $\begin{array}{c}0.91^{\star * *} \\
(0.08)\end{array}$ & $\begin{array}{c}0.91^{* * *} \\
(0.08)\end{array}$ & $\begin{array}{c}0.92 * * * \\
(0.08)\end{array}$ & $\begin{array}{c}0.92^{\star * *} \\
(0.08)\end{array}$ & $\begin{array}{c}0.91^{* * *} \\
(0.08)\end{array}$ & $\begin{array}{l}0.92^{\star \star \star} \\
(0.08)\end{array}$ \\
\hline Age & $\begin{array}{c}0.00 \\
(0.00)\end{array}$ & $\begin{array}{c}0.00 \\
(0.00)\end{array}$ & $\begin{array}{c}0.00 \\
(0.00)\end{array}$ & $\begin{array}{c}0.00 \\
(0.00)\end{array}$ & $\begin{array}{c}0.00 \\
(0.00)\end{array}$ & $\begin{array}{c}0.00 \\
(0.00)\end{array}$ & $\begin{array}{c}0.00 \\
(0.00)\end{array}$ & $\begin{array}{c}0.00 \\
(0.00)\end{array}$ & $\begin{array}{c}0.00 \\
(0.00)\end{array}$ & $\begin{array}{c}0.00 \\
(0.00)\end{array}$ \\
\hline Gender & $\begin{array}{c}-0.15^{\star \star \star} \\
(0.04) \\
\end{array}$ & $\begin{array}{c}-0.15^{\star \star *} \\
(0.04) \\
\end{array}$ & $\begin{array}{c}-0.15^{\star \star *} \\
(0.04)\end{array}$ & $\begin{array}{c}-0.15^{\star \star \star} \\
(0.04)\end{array}$ & $\begin{array}{c}-0.15^{\star \star *} \\
(0.04) \\
\end{array}$ & $\begin{array}{c}-0.16^{\star \star *} \\
(0.04) \\
\end{array}$ & $\begin{array}{c}-0.16^{\star \star \star} \\
(0.04)\end{array}$ & $\begin{array}{c}-0.16^{\star \star *} \\
(0.04)\end{array}$ & $\begin{array}{c}-0.15^{\star \star *} \\
(0.04)\end{array}$ & $\begin{array}{c}-0.15^{\star \star \star} \\
(0.04)\end{array}$ \\
\hline Cut point 1 & $\begin{array}{c}0.60 \\
(0.38)\end{array}$ & $\begin{array}{c}0.73 \\
(0.39)\end{array}$ & $\begin{array}{c}0.38 \\
(0.33)\end{array}$ & $\begin{array}{l}1.17^{\star *} \\
(0.41)\end{array}$ & $\begin{array}{c}0.44 \\
(0.33)\end{array}$ & $\begin{array}{l}0.77^{\star} \\
(0.36)\end{array}$ & $\begin{array}{l}1.09^{\star *} \\
(0.33)\end{array}$ & $\begin{array}{c}0.49 \\
(0.32)\end{array}$ & $\begin{array}{c}1.92^{\star * \star} \\
(0.41)\end{array}$ & $\begin{array}{l}0.84^{\star} \\
(0.36)\end{array}$ \\
\hline Cut point 2 & $\begin{array}{c}2.57^{\star \star \star} \\
(0.38)\end{array}$ & $\begin{array}{c}2.70^{\star \star \star} \\
(0.40)\end{array}$ & $\begin{array}{c}2.35^{\star \star \star} \\
(0.33)\end{array}$ & $\begin{array}{c}3.13^{\star \star \star} \\
(0.44)\end{array}$ & $\begin{array}{c}2.41^{\star \star \star} \\
(0.34)\end{array}$ & $\begin{array}{c}2.74^{\star \star \star} \\
(0.39)\end{array}$ & $\begin{array}{c}3.05^{\star \star \star} \\
(0.35)\end{array}$ & $\begin{array}{c}2.46^{\star \star \star} \\
(0.34)\end{array}$ & $\begin{array}{c}3.89 * \star \star \\
(0.43)\end{array}$ & $\begin{array}{c}2.81^{\star \star \star} \\
(0.37)\end{array}$ \\
\hline$B I C$ & 18767.99 & 18751.94 & 18792.14 & 18806.42 & 18783.07 & 18795.10 & 18786.44 & 18795.91 & 18805.23 & 18793.12 \\
\hline Log likelihood & -9309.62 & -9301.59 & -9321.69 & -9324.18 & -9317.15 & -9318.52 & -9318.84 & -9318.92 & -9323.59 & -9322.18 \\
\hline
\end{tabular}

for Stata (Rabe-Hesketh et al., 2005). Number of individuals: 10910 . Number of regions: 143 . Number of countries: 16 . ${ }^{*} p<.05,{ }^{\star *} p<.01,{ }^{\star \star \star} p<.001$ 
H1a is being operationalized using two product terms in models 1 and 2, one between National transfers and Direction of identity, and one between Subnational transfers and Direction of identity. Since the coefficient of a product term included in non-linear models alone does not allow for inferences about the magnitude and significance of the marginal effect of one variable on another, we plot all interaction terms (see Ai and Norton, 2003; Berry et al., 2010). The graphical depiction of the results from models 1 and 2 show that there is support for H1a. Model 1 is depicted in the left-hand panel of Figure 1, which shows how the statistical significance and magnitude of the marginal effect of National transfers on Support changes at different levels of Direction of identity (see Brambor et al., 2006). The solid line shows the estimated marginal effect on the probability that respondents pass a specific threshold $s$ on the variable Support and the dashed lines indicate the bounds of the 95 per cent confidence interval for this estimate. ${ }^{12}$ The marginal effect of National transfers is only statistically insignificant among citizens that definitely do not feel that they have a European identity. It is significant and increases among citizens that do not really, to some extent, or definitely have a European identity. The effect of national transfers on support appears to be strengthened among all citizens except for those that definitely do not feel that they have a European identity, lending strong support for H1a. This finding extends to subnational transfers. The righthand panel in Figure 1 shows a similar pattern for an increase of 500,000 Euro per capita in subnational transfers. Taken together, the results from models 1 and 2 endorse H1a in that they suggest that the positive effect of subnational transfers on support is strengthened the stronger a citizen's European identity. 
Table 2. Three-level models of Support - direct effects

\begin{tabular}{|c|c|c|c|}
\hline & Model 11 & Model 12 & Model 13 \\
\hline National transfers & $\begin{array}{c}0.17^{\star \star \star *} \\
(0.04)\end{array}$ & $\begin{array}{c}0.05 \\
(0.05)\end{array}$ & $\begin{array}{c}0.06 \\
(0.05)\end{array}$ \\
\hline Subnational transfers & $\begin{array}{l}-0.00^{\star *} \\
(0.00)\end{array}$ & $\begin{array}{l}-0.00 \\
(0.00)\end{array}$ & $\begin{array}{l}-0.00 \\
(0.00)\end{array}$ \\
\hline Direction of identity & $\begin{array}{c}0.88^{\star * \star *} \\
(0.04)\end{array}$ & $\begin{array}{c}0.87^{\star \star \star *} \\
(0.04)\end{array}$ & $\begin{array}{c}0.87^{* * *} \\
(0.04)\end{array}$ \\
\hline Strength of identity & $\begin{array}{c}0.02 \\
(0.06)\end{array}$ & $\begin{array}{c}0.02 \\
(0.06)\end{array}$ & $\begin{array}{c}0.02 \\
(0.06)\end{array}$ \\
\hline Education & $\begin{array}{c}0.10^{\star \star *} \\
(0.01)\end{array}$ & $\begin{array}{c}0.10^{\star \star *} \\
(0.01)\end{array}$ & $\begin{array}{c}0.10^{\star * *} \\
(0.01)\end{array}$ \\
\hline Discussion & $\begin{array}{c}0.01 \\
(0.05)\end{array}$ & $\begin{array}{c}0.01 \\
(0.05)\end{array}$ & $\begin{array}{c}0.00 \\
(0.05)\end{array}$ \\
\hline Party pos. on European redistribution & $\begin{array}{l}-0.10 \\
(0.06)\end{array}$ & $\begin{array}{l}-0.21^{* *} \\
(0.07)\end{array}$ & $\begin{array}{c}-0.21^{\star *} \\
(0.07)\end{array}$ \\
\hline Party pos. on European integration & $\begin{array}{l}0.07^{*} \\
(0.03)\end{array}$ & $\begin{array}{l}0.14^{\star *} \\
(0.04)\end{array}$ & $\begin{array}{l}0.14^{\star *} \\
(0.05)\end{array}$ \\
\hline Personal economic prospects & $\begin{array}{c}0.09 * \star \star \\
(0.02)\end{array}$ & $\begin{array}{c}0.09 * * \star \\
(0.02)\end{array}$ & $\begin{array}{c}0.09 * * \star \\
(0.02)\end{array}$ \\
\hline Country's economic prospects & $\begin{array}{c}0.20^{\star * *} \\
(0.05)\end{array}$ & $\begin{array}{c}0.20^{\star * *} \\
(0.05)\end{array}$ & $\begin{array}{c}0.20^{\star \star *} \\
(0.05)\end{array}$ \\
\hline Union membership & $\begin{array}{c}0.06 \\
(0.15)\end{array}$ & $\begin{array}{c}0.07 \\
(0.15)\end{array}$ & $\begin{array}{c}0.07 \\
(0.14)\end{array}$ \\
\hline Trust in government & $\begin{array}{c}0.91^{\star \star \star} \\
(0.08)\end{array}$ & $\begin{array}{c}0.91^{\star \star *} \\
(0.08)\end{array}$ & $\begin{array}{c}0.91^{\star \star *} \\
(0.08)\end{array}$ \\
\hline Age & $\begin{array}{c}0.00 \\
(0.00)\end{array}$ & $\begin{array}{c}0.00 \\
(0.00)\end{array}$ & $\begin{array}{c}0.00 \\
(0.00)\end{array}$ \\
\hline Gender & $\begin{array}{c}-0.15^{\star \star \star} \\
(0.04)\end{array}$ & $\begin{array}{c}-0.16^{\star \star *} \\
(0.04)\end{array}$ & $\begin{array}{c}-0.16^{\star \star *} \\
(0.04)\end{array}$ \\
\hline Manual worker & & $\begin{array}{l}-0.11 \\
(0.06)\end{array}$ & $\begin{array}{c}0.41 \\
(0.22)\end{array}$ \\
\hline GDP & & $\begin{array}{c}-0.02^{\star \star *} \\
(0.01)\end{array}$ & $\begin{array}{c}-0.02^{* *} \\
(0.01)\end{array}$ \\
\hline Manual worker * GDP & & & $\begin{array}{l}-0.01^{*} \\
(0.00)\end{array}$ \\
\hline Cut point 1 & $\begin{array}{c}0.40 \\
(0.33)\end{array}$ & $\begin{array}{l}-1.98^{*} \\
(0.90)\end{array}$ & $\begin{array}{l}-1.81^{*} \\
(0.92)\end{array}$ \\
\hline Cut point 2 & $\begin{array}{c}2.36^{\star \star \star} \\
(0.33)\end{array}$ & $\begin{array}{l}-0.01 \\
(0.90)\end{array}$ & $\begin{array}{c}0.16 \\
(0.92)\end{array}$ \\
\hline$B I C$ & 18792.59 & 18794.32 & 18797.35 \\
\hline Log likelihood & -9321.92 & -9322.78 & -9319.65 \\
\hline
\end{tabular}


We operationalize H1b using interaction terms between National transfers and Strength of identity as well as Subnational transfers and Strength of identity in models 3 and 4. However, the evidence does not corroborate H1b. The coefficients of the product terms as well as the corresponding interaction plots suggest that the effect of transfers on support is not contingent upon identity strength. ${ }^{13}$
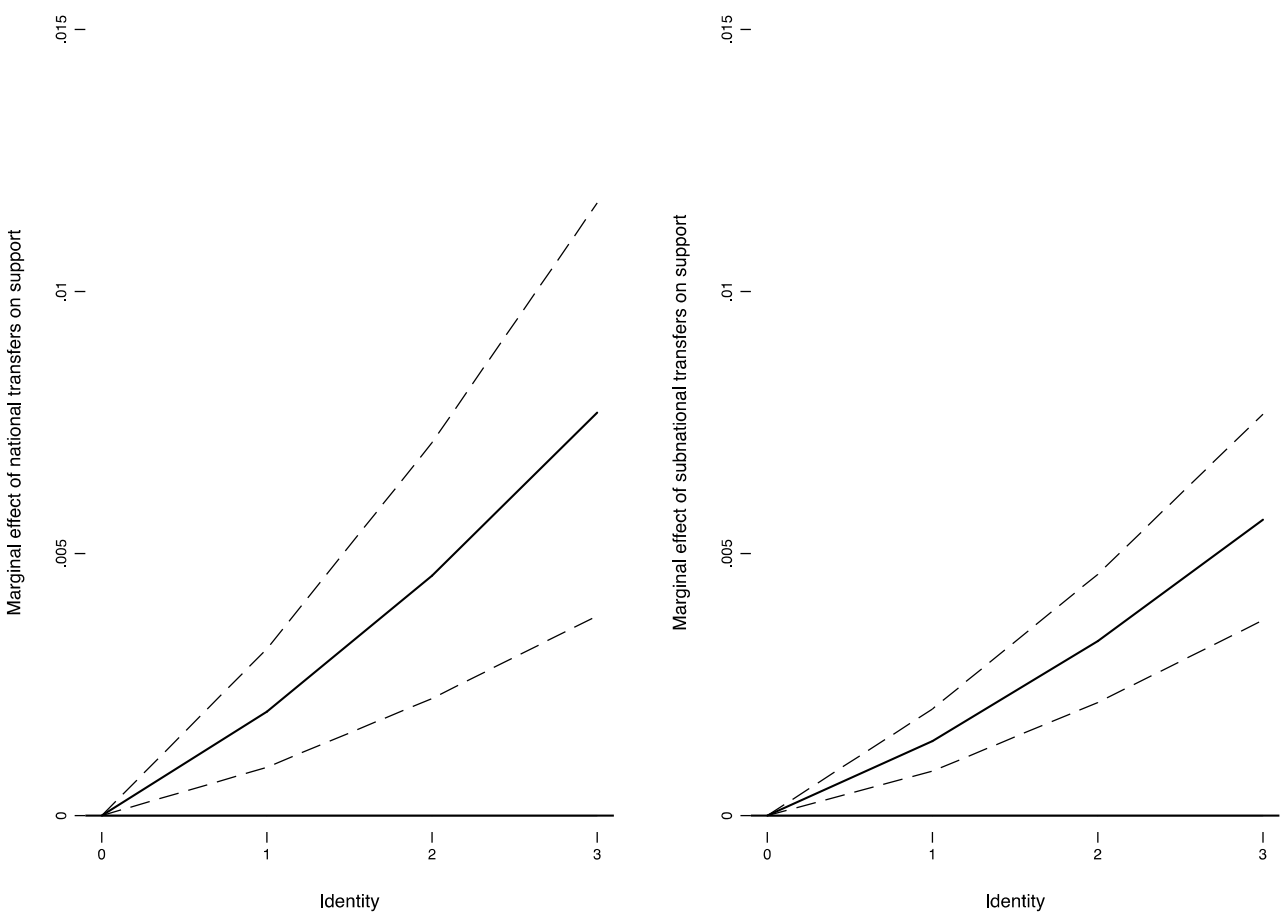

Figure 1: Effects of redistribution on Support at levels of Identity

Notes: Based on estimations in models 1 and 2. Solid line depicts the marginal effect on the latent dependent variable. Dashed lines depict the $95 \%$ confidence intervals of the marginal effect.

H2 is operationalized by including multiplicative terms between National transfers and Education as well as Subnational transfers and Education in models 5 and 6. Figure 2 depicts these product terms, showing that there is some support for H2. Both the effect of National transfers and Subnational transfers are positively significant at different levels of Education. Figure 2 suggests a substantial magnifying effect of education on the 
relationship between transfers and support. Yet, when using the alternative measure of political awareness in models 7 and 8, including the interaction terms Discussion and National transfers as well as Discussion and Subnational transfers, both interaction terms turn out to be insignificant. ${ }^{14}$ Taken together, the evidence provides mixed support for H2, suggesting that the better-educated are more likely to be impressed by EU transfers, whereas an effect of transfers is not contingent on the extent to which citizens discuss politics.
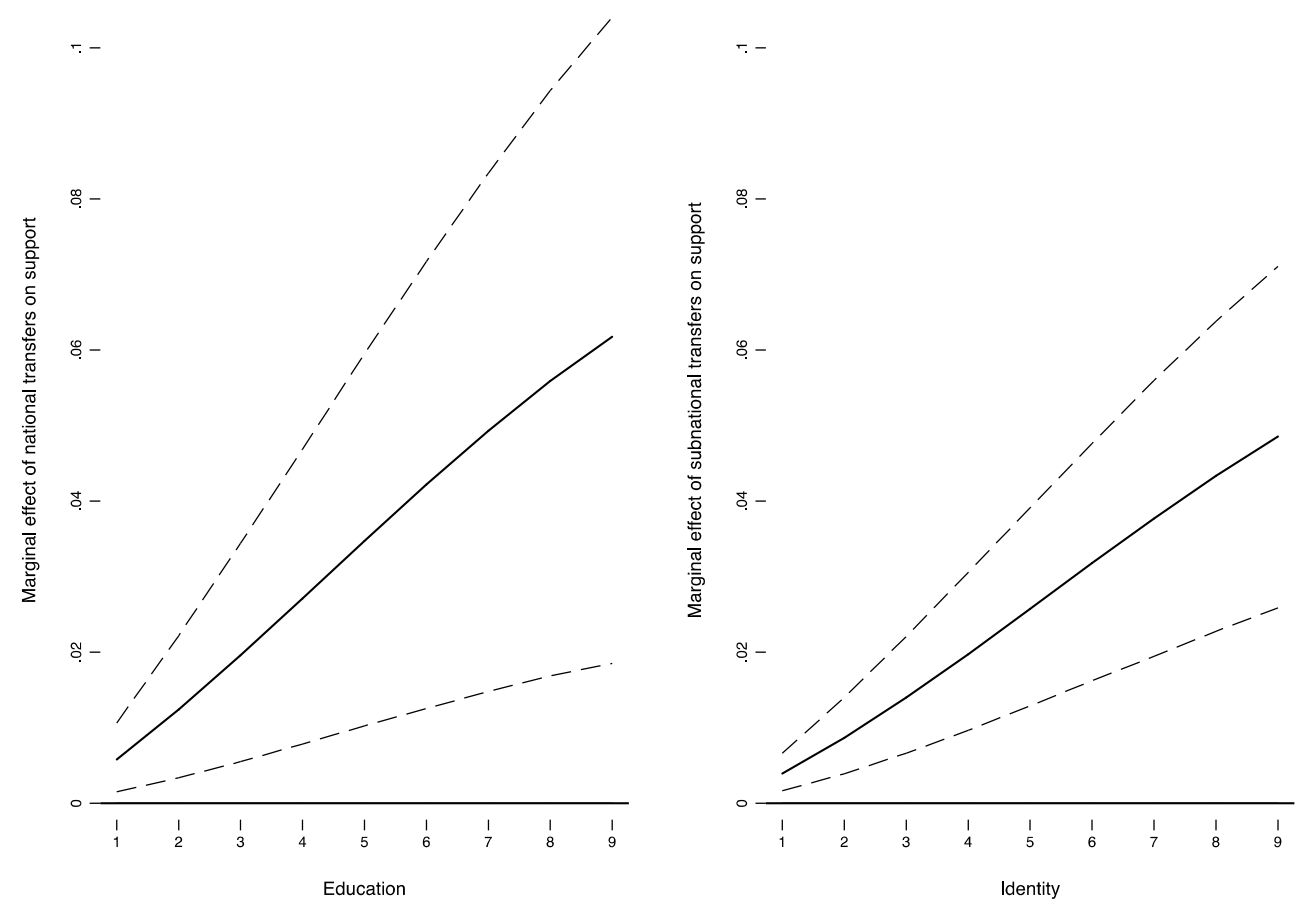

Figure 2. Effects of redistribution on Support at levels of Education Notes: Based on estimations in models 5 and 6 . Solid line depicts the marginal effect on the latent dependent variable. Dashed lines depict the $95 \%$ confidence intervals of the marginal effect.

Furthermore, the evidence does not corroborate H3. The effect of either transfer variable on support is not contingent upon party cues. Although the coefficients of the interaction 
terms from models 9 and 10 are statistically significant, plotting the interactions shows that there is no moderating effect of Party positions on European redistribution. ${ }^{15}$

Table 2 reports the regression models that test for a direct effect of national and subnational transfers on support. The evidence suggests that neither national transfers nor subnational transfers have a direct effect on support, which strengthens our confidence in the results reported in Table 1. By contrast, Identity and Education have a direct and positive effect on Support. Moreover, the two variables tapping economic self-interest, Personal economic prospects and Country's economic prospects, are significant. Furthermore, the interaction term for Manual worker and GDP is significant, but Union membership is not, implying mixed support for the explanation pertaining to material self-interest. A marginal effect plot shows that the effect of Manual worker on Support is negatively significant at different levels of GDP and magnified at higher levels of GDP. However, the upper 95 percent confidence interval is very close to zero, indicating relatively high uncertainty that there is in fact an effect. This suggests that manual workers may support the EU less especially if they live in richer countries (cf. Hooghe and Marks, 2005). ${ }^{16}$ The evidence also supports the logic of extrapolation, suggesting that support for European integration can be partially explained by citizens' trust in national political institutions (see Harteveld et al., 2013), corroborating the assumption that citizens know little about the EU and therefore evaluate European integration based on their experiences of political institutions at the domestic level (Armingeon and Ceka, 2014). Among the socio-demographic variables, age is insignificant, but the results show the gender gap in support for European integration. 


\section{Robustness of the results}

To test whether our findings hold across different model specifications, we conducted a series of robustness checks. First, we examine whether the explanatory power of the independent variables change when controlling for the extent to which a country's economy has been affected by the global financial crisis. To this end, we replicate all models in Tables 1 and 2 by including measures for the change in unemployment rates since the global financial crisis, coded as the difference between a country's unemployment rate in 2010 and in 2007, and measures for a country’s unemployment rate in $2010 .{ }^{17}$ However, some individuals might pay more attention to how well their country as a whole performs economically, whereas others may take their region as a reference point. Consequently, we run these robustness checks using country- and subnational-level measures, respectively. ${ }^{18}$ We provide an overview of the results from these analyses in Tables A6-A13 in the online appendix and plot the interaction terms. The results remain robust throughout. Interestingly, among the unemployment measures, we only find robust evidence that national unemployment rates explain part of the variation in support (see Table A9), which may be owing to the fact that this may be the most publicly visible economic indicator.

Second, we replicated all models by including moderately or highly correlated measures separately in the regression tables: National transfers and Subnational transfers $(r=0.826)$; Party positions on European redistribution and Party position on European integration $(r=0.534)$; and Personal economic prospects and Country's economic prospects $(r=0.542)$. The evidence from Tables A14-A20 in the online appendix and the corresponding interaction plots does not change the interpretation of our results. ${ }^{19}$ 
Finally, we replicated all analyses using alternative measures for transfers. Member state governments use their leeway to alter national transfers during the annual budgetary negotiations, even if they do not have much leeway (Schneider, 2013: 454). With regard to subnational transfers, the actual annual payments of funds may diverge from the payments decided at the beginning of the financial perspective, although these differences have been small in the past (Dellmuth and Stoffel, 2012: 430). To see whether annual bargaining processes matter, we re-run all analyses using, first, annual measures for both National transfers and Subnational transfers for 2010, and, second, aggregate measures for both transfer types for the years $2007-2010 .^{20}$ These changes to the model specifications also do not change the interpretation of our results (see Tables A21-A24 in the online appendix).

\section{Discussion of the results}

On balance, the hypotheses tested suggest that national and subnational transfers increase citizen support for European integration through two individual pre-dispositions: a communal identity and political awareness. In this respect, our results contradict and refine previous evidence about a direct effect of national transfers on EU support (e.g., Hooghe and Marks, 2004, 2005).

That the effect of national transfers on support is conditioned by one of the indicators for awareness, education, may be owing to the fact that better educated individuals have greater access to social and professional environments that make it more likely that they gather, maintain, and extend knowledge about politics in general (Highton, 2009), and, by extension, EU transfer payments, and to connect this knowledge 
to their attitudes towards European integration. Our findings suggest that better-educated individuals with a European identity are aware of national transfers, and probably they hold abstract knowledge about whether their country is a net contributor or net beneficiary. In this respect, our results tie in well with previous research arguing that national transfers affect EU opinion through sociotropic considerations about their country’s benefits from European integration (Hooghe and Marks, 2005).

The results presented in Table 2 do not yield robust evidence for a direct effect of national transfers or subnational transfers on support. Furthermore, those residing in countries where national parties think more positively about supranational redistribution are not more impressed by transfers. A possible explanation is that the process of allocating European transfer payments is not publicly discussed. The net contributor status may be politicized at the beginning of a budgetary period, but not in the middle of it. Alternatively, national political parties do not gain political support from politicizing and discussing subnational transfers. With regard to national transfers, political parties may not have an incentive to critically discuss them since they are not really involved in distributional bargaining in the Council; the key payers are national governments. Furthermore, national political parties may be more concerned about domestic redistribution than about European redistribution, also given that much less money is involved.

Additionally, higher support levels are found among citizens that worry less about their own or their country’s economic future, that have a communal European identity, and that trust more in domestic government (see Loveless and Rohrschneider, 2010). This can be seen when calculating the odds ratios for model 11, showing that the effects of 
identity and trust in domestic government are largest, and that the effects of variables tapping material interest and transfers are relatively small. For example, citizens in countries with an increase in national transfers by $0.1 \%$ of national GNI have $18 \%$ greater odds of thinking that European integration is a good thing as compared to thinking that it is neither good nor bad or bad. By contrast, citizens moving up one unit on trust in domestic government or on the communal identity scale, respectively, have more than twice the odds of supporting European integration to a greater extent. These results corroborate previous research showing that political predispositions, such as identity, have more explanatory power than indicators of material self-interest or sociotropic considerations when explaining support for European (e.g., Hooghe and Marks, 2005) or international trade integration (Mansfield and Mutz, 2009).

\section{Conclusion}

It is widely believed that redistribution in the EU is beneficial in several ways, among others to raise domestic capacity and support for European integration, thereby increasing the likelihood of member states complying with EU law (see Tallberg, 2002). Our results suggest that support is not merely a function of getting more money. The effects of transfers depend on communal identity and education, that is, factors that do not appear to be in the hands of European policy-makers. Furthermore, positive cues about European redistribution by national parties do not mediate an effect of transfers on support, suggesting that European transfers are not very politicized domestically. The analysis also indicates that identity-related predispositions have a stronger effect on support for European integration than economic considerations. 
The extent to which our findings regarding the EU can travel to other instances of regional and sectoral integration depends largely on the functional equivalences between fiscal transfers in the EU and fiscal transfers through the budgets of other regional organizations. As Dellmuth and Stoffel (2012: 428-429) highlight, there are other regional funding programs whose effects on public support for the EU may be studied, however survey data is not readily available and has to be collected for this purpose. Importantly, some regional development banks redistribute funds through grant programs that are similar to those of the EU. For example, the Development Bank of Southern Africa or the Asian Development Bank's allocate infrastructure grants to subnational authorities, among others, to further the organizations' policy goals. While such grant programs are typically not embedded in a larger budgetary framework similar to the EU's financial perspective, they are similar in terms of the recipients of the grants and the redistributive nature.

In light of these considerations, our results have implications for a broader literature on opinion towards international trade. Many authors have shown that distributional effects of trade on individual income drive support and opposition to it (e.g., Mayda and Rodrik, 2005; Scheve and Slaughter, 2001). However, there is considerable disagreement among scholars as to how and why economic self-interest shapes opinion on trade (e.g., Mansfield and Mutz, 2009) and international organizations (e.g., Dellmuth and Tallberg, 2014). Controversies on this issue among scholars of trade policy have typically involved the relative explanatory power of economic interests and identity (cf. Fordham and Kleinberg, 2012). Our results tie in with this literature in that 
they show that individual predispositions have more explanatory power than indicators of material interest.

Finally, the findings in this article open up potential avenues for further research. The effects of funding programs on support for regional and sectoral integration processes beyond the EU is not the only promising topic for further research. In line with a large body of research in American politics about the effect of self-interest on public opinion and voting behavior (e.g., Guisinger, 2009; Lewis-Beck and Stegmaier, 2000), the contingency of the effect of EU transfers on identity and education suggests that only some survey respondents may have a sound understanding about the relationship between fiscal redistribution through regional organizations and their material self-interest, and the implications for how they evaluate European integration. Hence, the cognitive and social processes linking fiscal and economic effects of a country’s exposure to regional and trade integration processes to a person's support for further integration remain relatively unexplored. Learning more about these individual-level and social processes would enable us to make better predictions of the likely consequences of regional and trade integration on people’s support for integration.

\section{References}

Ai C and Norton EC (2003) Interaction terms in logit and probit models. Economic Letters 80(1): 123-129.

Anderson CJ (1998) When in doubt, use proxies: Attitudes toward domestic politics and support for European integration. Comparative Political Studies 31(5): 569-601.

Anderson CJ and Reichert MS (1995) Economic benefits and support for membership in the 
EU: A cross-national analysis. Journal of Public Policy 15(3): 231-249.

Armingeon K and Ceka B (2014) The loss of trust in the European Union during the great recession since 2007: The role of heuristics from the national political system. European Union Politics 15(1): 82-107.

Bakker R, de Vries C, Edwards E, Hooghe L, Jolly S, Marks, G and Vachudova M (2012) Measuring party positions in Europe: The Chapel Hill expert survey trend file, 19992010. Party Politics. DOI: $10.1177 / 1354068812462931$

Berry WD, DeMeritt JHR and Esarey J (2010) Testing for interaction in binary logit and probit models: Is a product term essential?. American Journal of Political Science 54(1): 248-266.

Brambor T, Clark W and Golder M (2006) Understanding interaction models: Improving empirical analyses. Politcal Analysis 14(1): 63-82.

Bruter M (2003) Winning hearts and minds for Europe: The impact of news and symbols on civic and cultural European identity. Comparative Political Studies 36(10): 11481179.

Bruter M (2004) On what citizens mean by feeling 'European': Perceptions of news, symbols and borderless-ness. Journal of Ethnic and Migration Studies 30(1): 21-39.

Caldeira GA and Gibson JL (1995) The legitimacy of the Court of Justice in the European Union: Models of institutional support. American Journal of Political Science 89(2): 356-376.

Carey S (2002) Undivided loyalties. Is national identity an obstacle to European integration? European Union Politics 3(4): 387-413.

Carrubba CJ (1997) Net financial transfers in the European Union: Who gets what and why? 
The Journal of Politics 59(2): 469-496.

Carrubba CJ (2001) The electoral connection in European Union politics. Journal of Politics 63(1): 141-158.

Chalmers, AW (2013) Regional authority, transnational lobbying and the allocation of Structural Funds in the European Union. Journal of Common Market Studies 51(5): 815-831.

Christin Thomas and Trechsel A (2002) Joining the EU? Explaining public opinion in Switzerland. European Union Politics 3(4): 415-443.

De Vreese C and Boomgaarden H (2005) Projecting EU referendums: Fear of immigration and support for European integration. European Union Politics 6(1): 59-82.

Delli Carpini MX and Keeter S (1996) What Americans know about politics and why it matters. New Haven: Yale University Press.

Dellmuth LM (2011) The cash divide: The allocation of European Union regional grants. Journal of European Public Policy 18(7): 1016-1033.

Dellmuth LM and Stoffel MF (2012) Distributive politics and intergovernmental transfers: the allocation of European Union Structural Funds. European Union Politics 13(3): 413433.

Dellmuth LM and Tallberg J (2014) The social legitimacy of international organisations: Interest representation, institutional performance, and confidence extrapolation in the United Nations. Review of International Studies: available on CJO 2014.

Edwards MS (2006) Public opinion regarding economic and cultural globalization: Evidence from a cross-national survey. Review of International Political Economy 13(4): 587608. 
Eichenberg RC and Dalton RJ (1993) Europeans and the European Community: The dynamics of public support for European integration. International Organization 47(4): 507-534.

European Commission (2014) Evaluation. Data for Research. Available at http://ec.europa.eu/regional_policy/impact/evaluation/data_en.cfm

European Union (2014). EU budget 2013. Financial Report. Luxembourg: Publications Office of the European Union, appendix 3. Available at: http://ec.europa.eu/budget/biblio/publications/publications_en.cfm.

Fordham BO and Kleinberg KB (2012) How can economic interests influence support for free trade. International Organization 66(2): 311-328.

Gabel M (1998a) Economic integration and mass politics: Market liberalisation and public attitudes in the European Union. American Journal of Political Science 42(2): 936953.

Gabel M (1998b) Public support for European integration: An empirical test of five theories. The Journal of Politics 60(2): 333-354.

Gabel M and Palmer H (1995) Understanding variation in public support for European integration. European Journal of Political Research 27(1): 3-19.

Gabel M and Scheve K (2007) Estimating the effect of elite communications on public opinion using instrumental variables. American Journal of Political Science 51(4): 1013-1028.

Goldstein H (1987) Multilevel models in educational and social research. London: Charles Griffen.

Guisinger A (2009) Determining trade policy: Do voters hold politicians accountable? 
International Organization 63(3): 533-557.

Harteveld E, van der Meer T and De Vries CE (2013) In Europe we trust? Exploring three logics of trust in the European Union. European Union Politics 14(4): 1-24.

Highton B (2009) Revisiting the relationship between educational attainment and political sophistication, Journal of Politics 71(4): 1564-1576.

Hooghe L, Bakker R, Brigevich A, de Vries C, Edwards E, Marks, G and Steenbergen MR (2010) Reliability and validity of measuring party positions: The Chapel Hill expert surveys of 2002 and 2006. European Journal of Political Research 49(5): 684-703.

Hooghe L, and Marks G (2004) Does identity or economic rationality drive public opinion on European integration? PSOnline: 1-6.

Hooghe L, and Marks G (2005) Calculation, community and cues. Public opinion on European integration. European Union Politics 6(4): 419-443.

Hurd, I (1999) Legitimacy and authority in international politics. International Organization 53(2): 379-408.

Inglehart R (1970) Cognitive mobilization and European identity. Comparative Politics 3(1): $45-70$.

Inglehart R and Rabier J (1978) Economic Uncertainty and European Solidarity: Public Opinion Trends. Annals of the American Academy of Political and Social Sciences 440: 66-87.

Jhee B-K (2009) Public support for regional integration in Northeast Asia: An empirical test of affective and utilitarian models. International Political Science Review 30(1): 4965.

Kaltenthaler KC, Gelleny RD and Ceccoli SJ (2004) Explaining citizen support for trade 
liberalization. International Studies Quarterly 48(4): 829-851.

Karp JA, Banducci SA and Bowler S (2003) To know it is to love it? Satisfaction with democracy in the European Union. Comparative Political Studies 36(3): 271-292.

Kriesi H and Lachat R (2004) Globalization and the Transformation of the National Political Space: Switzerland and France Compared. Paper presented at the Workshop on the Analysis of Political Cleavages and Party Competition, Duke University.

Lewis-Beck MS and Stegmaier M (2000) Economic determinants of electoral outcomes. Annual Review of Political Science 3: 183-219.

Loveless, M and Rohrschneider R (2011) Public perceptions of the EU as a system of governance. Living Reviews of European Governance 6(2).

Luskin, RC (1987) Measuring political sophistication. American Journal of Political Science. 31: 857-889.

Maier M, Adam S and Maier J (2012) The impact of identity and economic cues on citizens' EU support: An experimental study on the effects of party communication in the runup to the 2009 European Parliament elections. European Union Politics 13(4): 580603.

Mansfield ED and Milner HV (2012) Votes, Vetoes, and the Political Economy of International Trade Agreements. Princeton: Princeton University Press. Mansfield ED and Mutz DC (2009) Support for free trade: Self-interest, sociotropic politics and out-group anxiety. International Organization 63(3): 425-457.

Marks G (1999) Territorial identities in the European Union. In Anderson J J (ed) Regional Integration and Democracy: Expanding on the European Experience. Boulder, CO: Rowman \& Littlefield, 69-91. 
Mayda, AM and Rodrik D (2005) Why are some people (and countries) more protectionist than others? European Economic Review 49(6): 1393-1430.

Muñoz J, Torcal M and Bonet E (2011) Institutional trust and multilevel government in the European Union: Congruence or compensation? European Union Politics 12(4): 551574.

Rabe-Hesketh S and Skrondal A (2008) Multi- level and Longitudinal Modelling Using Stata. Texas: Stata Press.

Rodden J (2002) Strength in numbers? Representation and redistribution in the European Union. European Union Politics 3(2): 151-175.

Rohrschneider R (2002) The democracy deficit and mass support for an EU-wide government. American Journal of Political Science 46(2): 462-475.

Scheve KF and Slaughter MJ (2001) What determines individual trade-policy preferences? Journal of International Economics 54(2): 267-292.

Schneider, CJ (2013) Globalizing electoral politics: Political competence and distributional bargaining in the European Union. World Politics 65: 452-490

Tallberg J (2002) Paths to compliance: Enforcement, management, and the European Union. International Organization 56(3): 609-643.

Tomz M (2007) Domestic audience costs in international relations: An experimental approach. International Organization 61(4): 821-840.

Wooldridge JM (2001) Econometric Analysis of Cross Section and Panel Data. Cambridge, M.A.: MIT Press.

Zaller JR (1992) The Nature and Origins of Mass Opinion. New York: Cambridge University Press. 


\section{End Notes}

${ }^{\mathrm{i}}$ We conceive of regions or subnational jurisdictions as covering all jurisdictions at local and intermediate levels below that of the state.

${ }^{\text {ii }}$ In 2010, 20 member states received transfer payments at the subnational level (European Commission, 2014). Of these member states, the following 16 member states are included in the data set: Austria, Belgium, Czech Republic, Denmark, Finland, Germany, Greece, Hungary, Italy, the Netherlands, Poland, Portugal, Slovak Republic, Spain, Sweden, and the United Kingdom (see Table A4 in the online appendix for a list of the subnational jurisdictions in these countries). Four of these member states (Bulgaria, Ireland, France, and Romania) are excluded from the data set since data on party positions were not available in the Chapel Hill Expert Survey (CHES), which we use to measure party positions on European redistribution and European integration.

iii Table A1 in the online appendix provides detailed information about the operationalization of the variables used for the empirical analysis and the robustness checks. Furthermore, tables A2 and A3 of the online appendix present descriptive statistics and correlations between the variables introduced in this section.

iv The amount of funds that countries and regions are entitled to is decided for a period of seven years and the annual expenditure ceilings are fixed (e.g., Articles 5 and 6 of Council regulation 1083/2006).

v Data was provided by the European Commission’s Directorate-General for Regional and Urban Policy and the general and regional statistical series available at http://epp.eurostat.ec.europa.eu/.

${ }^{v i}$ All subnational transfer measures are calculated using budgetary commitments and not budgetary payments (cf. Dellmuth and Stoffel, 2012).

vii Table A5 in the online appendix provides an overview of the years in which the national elections were held.

viii Available at: http://www.unc.edu/ hooghe/data_pp.php (accessed 21.5.2014).

${ }^{\text {ix }}$ We combined results for the CD\&V (Christian Democratic and Flemish) and the V NVA (New Flemish Alliance).

${ }^{\mathrm{x}}$ For the mathematical notation of the regression model see the online appendix B. 
${ }^{x i}$ In line with previous research examining transfer variables on support for European integration (e.g., Eichenberg and Dalton, 1993; Hooghe and Marks, 2005), we treat transfers as factors that simultaneously affect Support.

12 The response probabilities for Figure 1 are calculated following Wooldridge (2001: 505, equation 15.88), yielding $\mathrm{P}(\mathrm{y}=1 \mid \mathrm{x})$ at different levels of Direction of identity, and implemented in Stata by revising the code suggested by Brambor et al. (2006).

${ }^{13}$ Since the interaction terms from models 3 and 4 are not significant, we report the corresponding marginal effect plots in Figures C1 and C2 in the online appendix.

${ }^{14}$ We depict the interaction plots from models 7 and 8 in Figures C3 and C4 in the online appendix.

${ }^{15}$ We show the interaction plots from models 9 and 10 in Figures C5 and C6 in the online appendix.

${ }^{16}$ Since this finding is not part of our hypothesis test, we report the corresponding interaction plot in Figure C7 in the online appendix.

${ }^{17}$ Data for unemployment rates are not lagged. Since data on unemployment is typically frequently reported in the news media, measures for 2010 are better proxies for what citizens knew about unemployment in their country when the survey was conducted in May 2010 than the unemployment rates for 2009.

${ }^{18}$ We thank an anonymous reviewer for suggesting the inclusion of such indicators.

${ }^{19}$ Entering these variables separately in the regression models and plotting the interaction effects yields mixed evidence for a moderating effect of Party positions on European redistribution.

${ }^{20}$ We do not lag these transfer variables since the annual allocation of national transfers is being decided at the beginning of the budgetary period. 